\title{
Is home-based therapy in Fabry disease the answer to compelling patients' needs during the COVID-19 pandemic? Survey results from the Polish FD Collaborative Group
}

\author{
Mariusz Kusztal ${ }^{1, A-D}$, Mariusz Kłopotowski ${ }^{2, A, B, F}$, Stanisława Bazan-Socha ${ }^{3, A, C, E}$, Beata Błażejewska-Hyżorek ${ }^{4, B, C, E}$, \\ Krzysztof Pawlaczyk $k^{5,6, A, E, F}$, Andrzej Ok0 ${ }^{5, E, F}$, Magdalena Krajewska ${ }^{1, E, F}$, Michał Nowicki ${ }^{7, A, B, E, F}$ \\ ${ }^{1}$ Department of Nephrology and Transplantation Medicine, Wroclaw Medical University, Poland \\ 2 Department of Interventional Cardiology and Angiology, Institute of Cardiology, Warszawa, Poland \\ ${ }^{3}$ Department of Internal Medicine, Jagiellonian University Medical College, Kraków, Poland \\ ${ }^{4} 2^{\text {nd }}$ Department of Neurology, Institute of Psychiatry and Neurology, Warszawa, Poland \\ ${ }^{5}$ Department of Nephrology, Transplantology, and Internal Diseases, Poznan University of Medical Sciences, Poland \\ ${ }^{6}$ Department of Nephrology, University Hospital of Karol Marcinkowski, Zielona Góra, Poland \\ ${ }^{7}$ Department of Nephrology, Hypertension, and Kidney Transplantation, Medical University of Lodz, Poland \\ A - research concept and design; $\mathrm{B}$ - collection and/or assembly of data; $\mathrm{C}$ - data analysis and interpretation; \\ $D$ - writing the article; $E$ - critical revision of the article; $F$ - final approval of the article
}

Address for correspondence

Mariusz Kusztal

E-mail: mariusz.kusztal@umed.wroc.pl

Funding sources

None declared

\section{Conflict of interest}

The following authors declare potential conflict of interest: M.K. - consultation fees/speaker fees from Sanofi Genzyme and Takeda/Shire; B. B-H. - consultation fees/speaker fees from Sanofi Genzyme and Takeda/Shire; M.N. - consultation fees/speaker fees from Sanofi Genzyme, Takeda/Shire, symposium fee from Amicus. The other authors declare no conflict of interest.

Received on December 14, 2020

Reviewed on December 15, 2020

Accepted on December 30, 2020

Published online on April 28, 2021

Cite as

Kusztal M, Kłopotowski M, Bazan-Socha S, et at. Is homebased therapy in Fabry disease the answer to compelling patients' needs during the COVID-19 pandemic?

Survey results from the Polish FD Collaborative Group. Adv Clin Exp Med. 2021;30(4):449-454.

doi:10.17219/acem/132038

DOI

10.17219/acem/132038

Copyright

Copyright by Author(s)

This is an article distributed under the terms of the

Creative Commons Attribution 3.0 Unported (CC BY 3.0)

(https://creativecommons.org/licenses/by/3.0/)

\section{Abstract}

Background. Fabry disease (FD) is an X-linked disorder related to a deficiency of the lysosomal enzyme alpha-galactosidase A. In Poland, enzyme replacement therapy (ERT) for FD is offered by the National Health Fund only at selected hospital infusion centers. Patients with FB are considered at a high risk of developing complications from COVID-19. Some patients omitted infusions due to fear of infection or outbreaks in hospitals. Lack of alternative infusion sites hampered the situation.

Objectives. To analyze the impact of the SARS-CoV-2 pandemic on FD patients, especially their fears and expectations, the Polish FD Collaborative Group collaborated on a survey project.

Materials and methods. Between September and November 2020, we distributed a customized survey exploring expectations and fears among FD subjects.

Results. Fifty-five individuals ( 35 receiving ongoing ERT) from different FD centers completed the study. The median age was 40 years [IOR 25; 50], and gender distribution was almost equal (27 F; $28 \mathrm{M})$. Onefourth of FD patients reported severe disability limiting transportation for infusions that, in the opinion of the other $25 \%$ of responders, consumed $>4 \mathrm{~h}$. Forty-four (80\%) of all would prefer home infusions performed by a nurse $(n=37,67.3 \%)$ or by a trained non-medical person $(n=7,12.7 \%)$, while $8(14.5 \%)$ patients would choose a local hospital. As expected, transportation time (in one direction) was longer in those preferring home infusions ( $89.4 \pm 63$ vs $36.2 \pm 67 \mathrm{~min} ; p=0.02$ ). Also, those with more severe FD manifestation would prefer home infusions to treatment in FD centers ( $p=0.03$ ). The vast majority of respondents ( $n=46 ; 83 \%$ ) would not change their preferences after pandemic termination.

Conclusions. To maintain ERT, FD patients prefer home infusions or those given in the nearest hospital, especially during a pandemic.

Key words: COVID-19, enzyme replacement therapy, Fabry disease, home therapy, hospital infusion 


\section{Background}

Fabry disease (FD) is a rare lysosomal disorder characterized by deficiency of $\alpha$-galactosidase A activity resulting from mutations in the GLA gene (FD; OMIM \#301500; ORPHA: 324). In FD, progressive accumulation of lipids, primarily globotriaosylceramide (Gb3) and its deacylated derivative globotriaosylsphingosine (lyso-Gb3), lead to cell, tissue and multiorgan damage, and eventual failure. ${ }^{1}$

In Europe, FD has an estimated incidence of 1 in 100,000 inhabitants. While the exact prevalence in Poland is unknown, numbers provided by the association of families with FD indicate 73 patients, likely a major underestimation. Since September 2019, the only FD therapy offered by the Polish National Health Fund (NFZ) has been based on a two-enzyme replacement therapy (ERT) provided at hospitals' infusions centers (hospital-based ERT). Prior to 2019, most FD patients received ERT either in clinical trials or as a part of a compassionate drug therapy program provided by the pharmaceutical companies. ${ }^{2}$ At present, no patients in Poland receive home-based ERT.

The outbreak of the coronavirus disease 2019 (COVID-19) pandemic has become a major threat for humanity. The World Health Organization (WHO) declared the outbreak of COVID-19 a worldwide pandemic in March 2020. Globally, as of December 3, 2020, there have been 64.5 million confirmed cases of COVID-19, including 1.5 million deaths, reported to the WHO. ${ }^{3}$

The lessons learned from the disease outbreak in China, ${ }^{4,5}$ Italy and New York City ${ }^{6}$ showed that patients with comorbidities, particularly those with cardiovascular disease, are at a higher risk of complications and mortality. Regarding FD and other ultra-rare diseases, there are no reliable data indicating their predisposition to SARS-CoV-2 infection. Most adult FD patients, in fact, have chronic illnesses caused by the chronic accumulation of glycosphingolipids found in the lysosomes of most cell types and tissues, leading in time to dysfunction. The most common manifestations are heart failure, chronic kidney disease, recurrent/transient brain ischemia, gastrointestinal symptoms, hypertension, and skin edema/cellulitis. ${ }^{7}$ Therefore, a delay of therapy ${ }^{8}$ due to the collateral damage done by the pandemic, including the postponement of procedures or rescheduled hospital visits, places FD adults at risk of worsening their condition. Patients' fear of contact with other people and hospital workers has also been exaggerated by lockdown media news and the stayat-home order.

The situation during the first coronavirus wave in the spring was less dramatic for Polish FD patients, as the majority of patients avoided COVID-19. However, increased numbers during the current second wave indicate a more serious situation. By December 3, 2020, more than 1 million people in Poland had been infected with SARS-CoV-2 and 18,828 had died. Thus, a real risk of treatment discontinuation for FD patients appeared.
SARS-CoV-2-infected patients with FD may be isolated or admitted to COVID-19-dedicated hospitals where ERT is not available. In a few FD centers, visits were rescheduled due to the appearance of outbreaks of infection in the hospital. Due to these circumstances, increased numbers of FD patients began to ask in the FD centers why the treatment is not provided closer to their homes, or in their homes with or without nurse assistance. The social impact and the fear of recurrence of viral infections have put pressure on clinicians to change strategies in order to avoid therapy interruptions for patients.

\section{Objectives}

To analyze the impact of the SARS-CoV-2 pandemic on FD patients, especially their fears and expectations, the Polish FD Collaborative Group collaborated on a survey project. The results are presented below.

\section{Materials and methods}

\section{Survey and statistical analysis}

A customized survey (available as supplementary material) containing 24 questions was created. The anonymous survey was distributed to all FD patients visiting Fabry centers in Poland between September 20 and November 1, 2020. The patients provided verbal consent prior to filling out the survey and left it in a drop-box after completion. Anonymization allowed for quicker survey distribution (no data protection needed by our country law) and hopefully more honest answers, especially for some questions referring to the change of treating facility and place of infusion.

Demographic and clinical data, and all survey responses were entered into a database for this study. Descriptive analyses, the frequency distribution of variables, and comparative tests (Mann-Whitney U test, $X^{2}$ test, Student's t-test) were performed.

\section{Results}

\section{Patient characteristics}

Fifty-five patients responded by returning the filled survey. Four surveys were incompletely filled, but eventually considered useful as omissions were $<30 \%$ of the questions. Participating patients were from most Polish centers for FD located in Kraków, Łódź, Wrocław, Gdańsk, Warszawa, and Poznań.

Demographic and clinical characteristics are displayed in Table 1. The median age of the surveyed patients was 40 years [IQR 25;50], and gender distribution was almost 
Table 1. Demographic and clinical characteristics of patients

\begin{tabular}{|c|c|c|}
\hline Parameter & $\begin{array}{l}\text { Total; } \\
\mathrm{n}=55\end{array}$ & $\begin{array}{l}\text { Receiving ERT; } \\
\quad \mathrm{n}=35\end{array}$ \\
\hline $\begin{array}{l}\text { Age [years] [IQR] } \\
\text { Under } 18 \text { years }\end{array}$ & $\begin{array}{c}38.2 ;[25 ; 50]) \\
\text { median } 40 \\
3\end{array}$ & $\begin{array}{c}39.6 ;[26 ; 51] \\
\text { median } 37 \\
2\end{array}$ \\
\hline Gender & $27 F / 28 M$ & $13 \mathrm{~F} / 22 \mathrm{M}$ \\
\hline $\begin{array}{l}\text { Educational level } \\
\text { - elementary/basic } \\
\text { vocational school } \\
\text { - high school/technical } \\
\text { college } \\
\text { - university/college } \\
\text { - no response }\end{array}$ & $\begin{array}{l}10 \\
27 \\
17 \\
1\end{array}$ & $\begin{array}{c}7 \\
15 \\
12 \\
1\end{array}$ \\
\hline $\begin{array}{l}\text { Employment/learning } \\
\text { - employed } \\
\text { - unemployed } \\
\text { - disability pension } \\
\text { - retirement } \\
\text { - learning/studying } \\
\text { - no response }\end{array}$ & $\begin{array}{c}28 \\
1 \\
13 \\
4 \\
10 \\
1\end{array}$ & $\begin{array}{c}15 \\
1 \\
10 \\
3 \\
7\end{array}$ \\
\hline $\begin{array}{l}\text { Self-reliance } \\
\text { - complete } \\
\text { - with some effort } \\
\text { - incomplete (frequent } \\
\text { help of the other person) } \\
\text { - total dependence }\end{array}$ & $\begin{array}{l}25(45.5 \%) \\
19(34.5 \%) \\
7(12.7 \%) \\
4(7.3 \%)\end{array}$ & $\begin{array}{l}10(28.6 \%) \\
16(45.7 \%) \\
7(20 \%) \\
2(5.7 \%)\end{array}$ \\
\hline $\begin{array}{l}\text { General health perception } \\
\text { (scale } 1-10 ; 10 \text { - best) }\end{array}$ & $6.3 ;[5 ; 8]$ median 6 & $5.7 ;[4 ; 7]$ median 6 \\
\hline $\begin{array}{l}\text { Mean age at symptoms } \\
\text { onset [years] [IQR] }\end{array}$ & $\begin{array}{c}\text { 14.0; }[7 ; 18] \text { median } \\
9\end{array}$ & $\begin{array}{c}13.5 ;[7 ; 16] \text { median } \\
9\end{array}$ \\
\hline $\begin{array}{l}\text { Mean age at diagnosis } \\
\text { [years] [IQR] }\end{array}$ & $\begin{array}{l}28.2 ;[17 ; 40] \\
\text { median } 28\end{array}$ & $\begin{array}{l}27.8 ;[14.5 ; 41.5] \\
\text { median } 24\end{array}$ \\
\hline $\begin{array}{l}\text { Number of affected organs/ } \\
\text { systems (brain/heart/ } \\
\text { kidney/arteries/skin/eyes/ } \\
\text { ears/digestive tract/nervous } \\
\text { system/severe pain) }\end{array}$ & $\begin{array}{l}2.7 ;[1 ; 4] \\
\text { median } 2\end{array}$ & $\begin{array}{c}3.4 ;[2 ; 4] \\
\text { median } 3.5\end{array}$ \\
\hline $\begin{array}{l}\text { Severity of cases among } \\
\text { affected family members } \\
\text { (multiple choice) } \\
\text { - mild } \\
\text { - severe (heart/kidney } \\
\text { failure, stroke, severe pain) } \\
\text { - unknown }\end{array}$ & $\begin{array}{l}9(16.3 \%) \\
47(85.5 \%) \\
3(5.4 \%)\end{array}$ & $\begin{array}{c}6(17.1 \%) \\
26(74.3 \%) \\
3(8.5 \%)\end{array}$ \\
\hline $\begin{array}{l}\text { Treatment } \\
\text { - ERT } \\
\text { - Oral chaperon } \\
\text { No treatment: no or minor } \\
\text { symptoms } \\
\text { - I don't want to be } \\
\text { treated } \\
\text { - I have nowhere to be } \\
\text { treated } \\
\text { - I've been treated, but I'm } \\
\text { no longer } \\
\text { - waiting for the drug } \\
\text { - no response }\end{array}$ & $\begin{array}{c}35 \\
1 \\
11 \\
2 \\
2 \\
1 \\
2 \\
1\end{array}$ & 35 \\
\hline
\end{tabular}

ERT - enzyme replacement therapy.

equal (27 women and 28 men). Four surveys were completed by someone other than the patient (i.e., 3 by parents and 1 by a caregiver). The majority of FD patients (63.3\%) were receiving ERT-hospital infusions. In 20 FD patients,

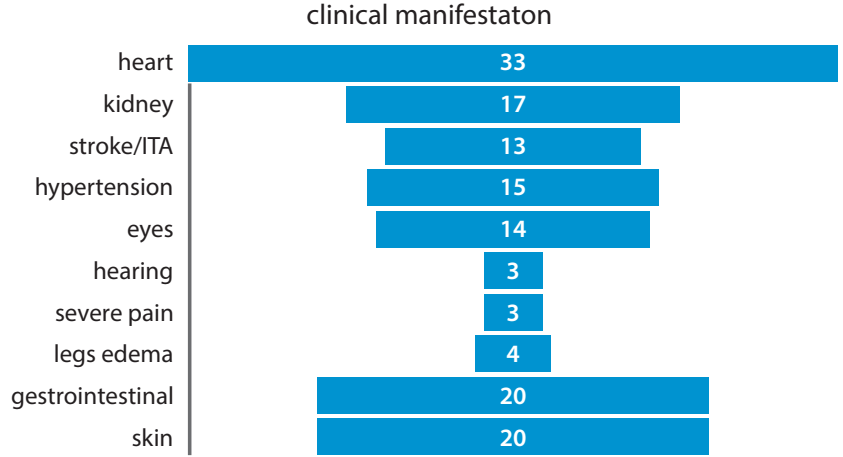

Fig. 1. Clinical manifestation of Fabry disease in entire cohort $(n=55)$

treatment was not provided mainly due to minor symptoms or a lack of symptoms.

The disease characteristics of the surveyed group are shown in Fig. 1. The median age of symptoms onset was 9 years [IQR 7;18] and the age of diagnosis 28 years [IQR 17;40]. Patients treated with ERT began therapy relatively late, namely at a median age of 30 years [IQR 16; 47]. The family burden by created FD was prominent - the vast majority (85.5\%) reported to have at least 1 member with a severe course (heart/kidney failure, stroke, severe pain).

General health perception (1-10 points; 10 - means best) was 6.3 in total, and 5.7 in ERT-treated patients. This was in line with the median number of affected organs -2 [IQR 1;4] and 3.5 [IQR 2;4], respectively.

\section{Functioning and reaching hospitals for infusions}

The majority (69\%) of patients were active workers $(50.9 \%$ employed, $18.1 \%$ studying). Self-reliance was reported by $45.5 \%$, and partial independence by $34 \%$. Disability of various degrees was reported by $20 \%$ of the whole group, and in $25.7 \%$ of those already receiving ERT.

The median time to reach the hospital (in one direction) for infusions was $60 \mathrm{~min}$ [IQR 20; 120]; however, $1 / 4$ of patients spent 4 or more hours on transportation. If we add a few hours for the infusion and hospital visit, it takes the whole day for these patients, and sometimes their caregivers (up to 25\%), to receive treatment. More than half of the surveyed FD patients never experienced infusion-related reactions, while $40 \%$ experienced a few episodes (Table 2).

\section{Home infusions as a potential therapy option}

Most patients on ERT (82.9\%) believed that therapy provided closer to home would be more convenient. However, some of them (22.6\%) admitted that a disadvantage of treatment closer to home is that local doctors know less about FD management (Table 2). From all the surveyed cohort, 37 patients (67.3\%) would choose home infusions performed 
Table 2. Experienced obstacles in transportation and infusions of FD patients receiving enzyme replacement therapy $(E R T ; n=35)$

\begin{tabular}{|l|c|}
\hline Mean time to reach the hospital (in 1 direction; & $75 ;[20 ; 120]$, \\
minutes) [IQR] & median 60 \\
- $\geq 20$ min & $9(25.7 \%)$ \\
- $<30$ min & 9 \\
- 30-59 min & 9 \\
- $60-119$ min & 7 \\
\hline Means of transport to the hospital/center & \\
(multiple choice) & \\
- public transport & $9(25.7 \%)$ \\
- own car & 17 \\
- friend or family member car & 7 \\
- by bike/walk & 2 \\
Difficult peripheral cannulation & \\
- no & 24 \\
- yes (including 2 with ports) & $11(31.4 \%)$ \\
\hline History of infusion-related reaction & \\
- few episodes & $14(40 \%)$ \\
- frequently & 1 \\
- never & $19(54.3 \%)$ \\
\hline Is it better to be treated closer or further from & \\
place of residence? (multiple choice) & \\
- treatment closer to home is more convenient & $29(82.9 \%)$ \\
- the weak side of treatment closer to home is & \\
the fact that local doctors know less about FD & $8(22.6 \%)$ \\
- it doesn't matter to me where I'm treated & \\
\hline
\end{tabular}

by a nurse, at a local hospital $(\mathrm{n}=8,14.5 \%)$, or at home by a trained non-medical person $(\mathrm{n}=7,12.7 \%)$. Interestingly, less experienced patients with fewer symptoms (and not on ERT) would more often choose home-based infusions than those receiving ERT (Table 3). Regardless of treatment experience, the time spent on transportation for hospital-based infusions may be decisive. Namely, transportation time (in one direction) varied significantly between patients choosing infusions at home and the remainder (89.4 \pm 63 compared to $36.2 \pm 67 \mathrm{~min} ; \mathrm{p}=0.02)$. Another factor distinguishing those preferring home-based from other sites is more severe FD manifestation defined by the presence of at least 1 of the following conditions: heart/kidney failure, stroke or severe pain. Those with severe FD would more frequently opt for home therapy than the others $(\mathrm{p}=0.03)$.

With regard to possible problems and worries associated with home infusions, our respondents indicated mainly vascular access (10-17\%), infusion-related reactions (11$20 \%$ ) and getting to the nearest hospital within an hour $(5-8.5 \%)$ as concerns.

Table 3. Home infusions as therapy option in the opinion of both treated and untreated FD patients

\begin{tabular}{|c|c|c|c|}
\hline Survey question & $\begin{array}{l}\text { In total } \\
(n=55)\end{array}$ & $\begin{array}{l}\text { Receiving ERT } \\
\quad(n=35)\end{array}$ & $\begin{array}{l}\text { Untreated } \\
\qquad(n=20)\end{array}$ \\
\hline $\begin{array}{l}\text { Preferred place of therapy infusion (multiple choice)* } \\
\text { - university hospital/institute } \\
\text { - hospital in the place of residence } \\
\text { - local clinic in the place of residence } \\
\text { - infusions at home by a doctor and nurse } \\
\text { - infusions at home by a nurse } \\
\text { - infusions at home by a trained person } \\
\text { - no opinion }\end{array}$ & $\begin{array}{c}3 \\
8(14.5) \\
1 \\
1 \\
37(67.3 \%) \\
7(12.7 \%) \\
2\end{array}$ & $\begin{array}{c}2 \\
7(20 \%) \\
1 \\
1 \\
19(54.2 \%) \\
9(16.4 \%) \\
1\end{array}$ & $\begin{array}{c}1 \\
1(5 \%) \\
0 \\
0 \\
18(90 \%) \\
2(10 \%) \\
1\end{array}$ \\
\hline $\begin{array}{l}\text { Worried about potential problems during home infusions (multiple choice) } \\
\text { - none } \\
\text { - } \text { difficult vein cannulation } \\
\text { - infusion related reactions } \\
\text { - } \text { getting to the nearest hospital within an hour }\end{array}$ & $\begin{array}{l}35(63.6 \%) \\
8(14.5 \%) \\
8(14.5 \%) \\
4(7.3 \%) \\
2(3.6 \%)\end{array}$ & $\begin{array}{l}21(60 \%) \\
6(17.1 \%) \\
4(11.4 \%) \\
3(8.5 \%) \\
2(5.7 \%)\end{array}$ & $\begin{array}{l}14(70 \%) \\
2(10 \%) \\
4(20 \%) \\
1(5 \%) \\
0\end{array}$ \\
\hline $\begin{array}{l}\text { If the SARS-CoV-2 pandemic will be over or an effective vaccine appears I will } \\
\text { change my preferences regarding where the infusions are to be made } \\
\text { - yes } \\
\text { - no } \\
\text { - no response }\end{array}$ & $\begin{array}{c}5 \\
48(87.3 \%) \\
2\end{array}$ & $\begin{array}{c}3 \\
31(88.6 \%) \\
1\end{array}$ & $\begin{array}{c}2 \\
17(85 \%) \\
1\end{array}$ \\
\hline $\begin{array}{l}\text { Transportation and administration of hospital-based therapy during an epidemic } \\
\text { may increase the risk of infection } \\
\text { - Yes, regardless of protective measures maintained } \\
\text { - Yes, but only when protective measures are omitted } \\
\text { - No, while maintaining protective measures } \\
\text { - No, regardless of protective measures maintained }\end{array}$ & $\begin{array}{l}33(60 \%) \\
8(14.5 \%) \\
11(20 \%) \\
3(5.5 \%)\end{array}$ & $\begin{array}{l}21(60 \%) \\
5(14.3 \%) \\
8(22.9 \%) \\
1(2.8 \%)\end{array}$ & $\begin{array}{l}12(60 \%) \\
3(15 \%) \\
3(15 \%) \\
2(10 \%)\end{array}$ \\
\hline $\begin{array}{l}\text { I am afraid that coronavirus may affect my health condition } \\
\text { - No, infection is often asymptomatic } \\
\text { - Yes, like any other infection } \\
\text { - Yes, coronavirus if more dangerous than other infections }\end{array}$ & $\begin{array}{c}3(5.5 \%) \\
24(43.6 \%) \\
28(50.9 \%)\end{array}$ & $\begin{array}{c}2(5.8 \%) \\
11(31.4 \%) \\
22(62.8 \%)^{* *}\end{array}$ & $\begin{array}{c}1(5 \%) \\
13(65 \%) \\
6(30 \%)\end{array}$ \\
\hline
\end{tabular}

*43 responders chose one option; ** chi-square $p<0.05$. 


\section{Impact of SARS-CoV-2 on FD patients' expectations regarding infusion sites}

To verify whether the preferences are situational and transient, we asked the following question: "Would you change preferences regarding infusion site if the SARSCoV-2 pandemic will be finished or an effective vaccine will be available?" The vast majority of subjects (87.3\%) responded negatively (Table 3 ).

From all the surveyed patients, 41 (74.5\%) expressed concern that transportation and administration of hospitalbased therapy during an epidemic may increase infection risk. That is, a generalized fear of potentially infected people further compounded concerns, regardless of protective measures maintained (Table 3).

Furthermore, anxiety that infection with SARS-CoV-2 may affect the health condition of FD patients is common. More ERT-treated than non-treated patients believed that SARS-CoV-2 is more dangerous than other infections (62.8\% compared to $30 \%$; $\mathrm{p}<0.05)$. This difference may be due to a higher burden of the disease in the ERT group.

\section{Discussion}

Nowadays, besides mortality, patient-reported outcomes (PRO) and patients' quality of life are considered significant treatment endpoints. This refers to all chronic illnesses, including FD, which need to be diagnosed on time and adequately treated for relatively normal functioning. Fortunately, ERT, substrate reducing therapy and chaperone drugs show effectiveness in treating this disease. As of November 2020, the only reimbursed therapy in Poland was agalsidase infusions carried out in hospital. Due to the SARS-CoV-2 pandemic, the risk of ERT discontinuation emerged and an increase in patients' anxiety raised the question of optional home-based treatment. The pandemic additionally revealed to us the needs of severely affected patients. The FD Collaborative group survey showed a significant burden for patients and their families when getting hospital infusions, especially for those with a physical disability. Based on a customized survey, it was revealed that $25 \%$ of FD patients receiving ERT spend 4 or more hours only for transportation, plus an additional few hours for the hospital visit and infusion. Moreover, 25\% of them need frequent or full support from others, which produces an additional family burden.

The majority of ERT receiving patients expressed the opinion that therapy provided at home or closer to home would be more convenient. Among the factors indicating a strong preference for home infusions were transportation time to the hospital and a more severe FD course.

Based the on survey results, we found that anxiety related to infection risk with SARS-CoV-2 is common in FD patients and even more expressed among ERT patients.
However, interestingly, patients' preferences and needs are somewhat not situational due to the coronavirus pandemic - the vast majority of them declared that they would not change infusion site after pandemic termination or in a case of adequate vaccination availability. This suggests that the pandemic is not the primary motive for choosing the place of ERT administration.

Well-organized home-therapy seems to be the most efficient way to maintain ERT access during the SARS-CoV-2 pandemic in many European countries. For instance, an Italian experience with a home infusion of agalsidase during the COVID-19 pandemic has demonstrated no increase in infection during the first wave in the spring. ${ }^{9}$ The absence of disease in the Naples's example could be due to the particular attention that this category of patients pays to respecting hygiene and infection prevention measures, and previously practiced and proven home-therapy with telemedicine for monitoring and supervision.

Regarding other lysosomal storage disorders like Gaucher disease (GD), where ERT is widely practiced, similar observations were made during the coronavirus pandemic. Patients with GD receiving oral therapy did not suffer problems with the medicine supply; 1 of the 16 patients receiving ERT in a home-based manner missed 1 dose, and $49 \%$ of the patients receiving therapy at hospitals experienced a treatment disruption. ${ }^{10}$

\section{Limitations}

Our data strongly suggest that we should offer homebased infusions or at least infusions in nearby facilities for FD patients. However, as it has been reported, home infusions have several limitations. They require dedicated training and several requirements before starting. ${ }^{11-13}$ Nonetheless, we estimate that currently $30-50 \%$ of Polish FD patients would be eligible for ERT home infusions. We might relate $10-15 \%$ of further discontinuation due to vascular access problems or infusion-related reactions.

\section{Conclusions}

Our findings reflecting FD patients' needs and expectations underline the necessity of new ways to ensure therapy regarding patient burden and safety. It seems that homebased therapies need to be considered in most FD patients and should be an option for a specific group of patients.

\section{ORCID iDs}

Mariusz Kusztal (D) https://orcid.org/0000-0002-6502-0374 Mariusz Kłopotowski (D) https://orcid.org/0000-0002-4316-5417 Stanisława Bazan-Socha (1) https://orcid.org/0000-0001-9634-0963 Beata Błażejewska-Hyżorek (1) https://orcid.org/0000-0002-6096-2952 Krzysztof Pawlaczyk (D) https://orcid.org/0000-0001-6237-0814 Andrzej Oko (D) https://orcid.org/0000-0002-3394-7140 Magdalena Krajewska (D) https://orcid.org/0000-0002-2632-2409 Michał Nowicki (D) https://orcid.org/0000-0002-0823-5440 


\section{References}

1. Germain DP. Fabry disease. Orphanet J Rare Dis. 2010;5:30. doi:10. 1186/1750-1172-5-30

2. Bazan-Socha S, Kuczia P, Musiał J, Błażejewska-Hyżorek B. Fabry disease in Poland. Pol Arch Intern Med. 2018;128:567-568. doi:10.20452/ pamw.4342

3. World Health Organisation (WHO) Coronavirus Disease (COVID-19) Dashboard, 2020. https://covid19.who.int/. Updated December 3, 2020 (7 PM CET)

4. Zhou F, Yu T, Du R, et al. Clinical course and risk factors for mortality of adult inpatients with COVID-19 in Wuhan, China: A retrospective cohort study. Lancet. 2020;395:1054-1062.

5. Guan WJ, Ni Z, Hu Y, et al. Clinical characteristics of coronavirus disease 2019 in China. N Engl J Med. 2020;382:1708-1720. doi:10.1056/ NEJMoa2002032

6. Cummings MJ, Baldwin MR, Abrams D, at al. Epidemiology, clinical course, and outcomes of critically ill adults with COVID-19 in New York City: a prospective cohort study. Lancet. 2020;395:1763-1770. doi:10.1016/S0140-6736(20)31189-2

7. MacDermot KD, Holmes A, Miners AH. Anderson-Fabry disease: clinical manifestations and impact of disease in a cohort of 60 obligate carrier females.J Med Genet. 2001;38:769-775. doi:10.1136/jmg.38.11.769
8. Palmer K, Monaco A, Kivipelto M, et al. The potential long-term impact of the COVID-19 outbreak on patients with non-communicable diseases in Europe: consequences for healthy ageing. Aging Clin Exp Res. 2020;32:1189-1194. doi:10.1007/s40520-020-01601-4

9. Sechi A, Macor D, Valent S, et al. Impact of COVID-19 related healthcare crisis on treatments for patients with lysosomal storage disorders, the first Italian experience. Mol Genet Metab. 2020;130:170-171. doi:10.1016/j.ymgme.2020.04.002

10. Politei J. Fabry disease during the COVID-19 pandemic. Why and how treatment should be continued. Mol Genet Metab. 2020;130:227-229. doi:10.1016/j.ymgme.2020.06.002

11. Milligan A, Hughes D, Goodwin S, Richfield L, Mehta A. Intravenous enzyme replacement therapy: better in home or hospital? Spotlight on agalsidase beta in Fabry disease. Br J Nurs. 2006;15:330-333. doi:10. 12968/bjon.2006.15.6.20681

12. Linthorst GE, Vedder AC, Ormel EE, Aerts JM, Hollak CE. Home treatment for Fabry disease: practice guidelines based on 3 years experience in The Netherlands. Nephrol Dial Transplant. 2006;21:355-360. doi:10.1093/ndt/gfi221

13. Kisinovsky l, Cáceres G, Coronel C, Reisin R. Home infusion program for Fabry disease: experience with agalsidase alfa in Argentina. Medicina (B Aires). 2013;73:31-34. 